\title{
Featural Faithfulness in Consonantal Repairs of Arabic Loanwords in Sundanese
}

\author{
Saleh Batais \\ Department of English Language and Literature, College of Arts, King Saud University, Saudi Arabia
}

Copyright $\bigcirc 2019$ by authors, all rights reserved. Authors agree that this article remains permanently open access under the terms of the Creative Commons Attribution License 4.0 International License

\begin{abstract}
This paper provides an Optimality-Theoretic account of the consonantal repairs employed by Standard Sundanese to adapt seven illicit Arabic consonants in Arabic loanwords and thus bring them into conformity with its phonemic system. The study supports Best's Perceptual Assimilation Model (PAM), which posits that the unfamiliar consonants are perceived to their closest native counterparts in terms of articulatory features. It has been found that all seven Arabic consonants are replaced with native Sundanese counterparts with, first and foremost, the same major articulator (i.e., labial or coronal: IDENT (ARTICULATOR)) and voicing quality (i.e., [ \pm voice]: IDENT (VOICE)), followed by the same manner of articulation (i.e., IDENT (MANNER)), which is preserved in the adaptation of five Arabic consonants only. In addition, while the source place (i.e., IDENT (PLACE)) and stridency (i.e., IDENT (STRIDENCY)) features are matched in only three adaptations each, IDENT (C) (i.e., no change of features) is never reflected in the data. Moreover, the adaptation of Arabic consonants satisfies markedness restrictions (represented by *EMPhAtic, *LABiodental, *Dental, $* / f /, * / z /$, and $* / \delta /$ ) in Sundanese phonology against the importation of Arabic consonants. This is captured by the following OT constraint ranking: MARKEDNESS, IDENT (ARTICULATOR), IDENT (VOICE) $>>$ IDENT (MANNER) $>>$ IDENT (PLACE) $>>$ IDENT $(\mathrm{C})$. In conclusion, this paper contributes to the insufficiently researched area of Sundanese loanword phonology.
\end{abstract}

Keywords Sundanese, Loanword Phonology, Optimality Theory, Adaptation, Featural Faithfulness

\section{Introduction}

Loanword adaptation is a process whereby a repair is triggered to modify an ill-formed foreign sound, syllable, or a suprasegmental feature in order to fit the sound system of the borrowing language. This paper is concerned with the repairs of seven Arabic consonants, namely $/ \mathrm{f} /, / \theta /, / \mathrm{z} /, / \mathrm{d}^{\mathrm{\varsigma}} /, / \mathrm{t}^{\mathrm{\varsigma}} /, / \mathrm{s}^{\mathrm{\varsigma}} /$, and $/ \mathrm{s} /$, in Arabic loanwords in Standard Sundanese, an Austronesian language spoken in West Java, Indonesia. Relying on these consonantal repairs and couched in Optimality Theory (henceforth, OT), this paper is intended to test Best's [1] Perceptual Assimilation Model (PAM), which affirms that the non-native segments are perceptually assimilated to native segments based on their articulatory closeness. The analyses of the seven consonantal repairs confirm the important role of featural faithfulness, as well as structural markedness in the mappings of the Arabic consonants onto their Sundanese counterparts. I employ the IDENT constraints to illustrate the importance of similarity in articulatory features between the Arabic input segment and the Sundanese output segment. In addition, I use a set of markedness constraints to exclude some Arabic segments from occurring in Arabic loanwords in Standard Sundanese. That is, such Arabic consonants are banned in the phonemic consonantal system of Standard Sundanese. This paper is intended to make a contribution to the rarely researched area of Sundanese loanword phonology.

The remainder of the paper is organized as follows: section 2 provides an overview of Sundanese lexical borrowing and the consonantal sound systems of Modern Standard Arabic and Standard Sundanese; section 3 lays out the theoretical foundation upon which the study is based; section 4 describes the sources from which the loanwords in this paper were collected and lists the consonantal changes evident in the data; section 5 analyzes and discusses the seven consonantal repairs attested in the Sundanese adaptation of Arabic loanwords; and section 6 concludes the discussion.

\section{Linguistic Background}

Sundanese (also known as Basa Sunda) belongs to the Malayo-Polynesian language family and is spoken by nearly 40 million people, predominantly in West Java, Indonesia [2]. Based on the geographical locations of its speakers, Sundanese has four main dialect areas: Banten, 
Bogor, Cirebon, and Priangan [3]. Despite variations in pronunciation and vocabulary, these four dialects are more or less mutually intelligible [4]. While Indonesian (also known as Bahasa Indonesia) is the official and national language of Indonesia, Sundanese has the status of a regional language and is restricted to communication within the family circle, among close friends, and between villagers [5].

In this section, I first provide a general account of the lexical borrowing process employed by Sundanese to enrich its lexicon and highlight its direct contact with Arabic. Second, I list the phonemic consonantal inventories of the two languages in focus, namely Arabic and Sundanese.

\subsection{Lexical Borrowing}

Owing to the Buddhist-Hindu, Islamic, European, and Javanese influences in the Indonesian archipelago, Sundanese has been in varying degrees of contact with foreign languages such as Sanskrit, Arabic, Dutch, and Portuguese, and regional languages such as Javanese. Such contact has resulted in influxes of lexical borrowings entering the Sundanese lexicon. For example, thanks to the arrival of Arab traders and their subsequent introduction of Islam into the region in the seventh century (Van Syoc [6], Manger [7], Jacobsen [8, 9]), Arabic has contributed significantly to the Sundanese lexicon, not only in domains relevant to Islamic concepts and practices (e.g., solat "prayer", ibadah "worship", and haji "pilgrim"), but also in daily vocabulary (e.g., murid "student", pikir "think", and yatim "orphan"). According to Van Syoc [6], words of Arabic origin account for approximately 6.5 percent of Satjadibrata's (1950) Sundanese-Indonesian Dictionary.

\subsection{Consonantal Inventories}

In this section, I present the phonemic consonantal inventory of Modern Standard Arabic followed by that of Standard Sundanese.

\subsubsection{Modern Standard Arabic}

Modern Standard Arabic ${ }^{1}$ has 28 phonemically distinct consonants. As illustrated in Table 1, adapted from Bateson [10] and Ryding [11], these are divided according to two voicing qualities, ten places of articulation, and seven manners of articulation. In addition, to distinguish further between the interdental and alveolar obstruents, Arabic employs a fourth feature, the emphasis feature. The term "emphasis" is described as a secondary articulation in the pharynx (i.e., pharyngealization) in addition to the primary articulation in the vocal tract [12] [13]. Therefore, the IPA superscript symbol of the voiced pharyngeal consonant $[\mathrm{G}]$ is used to represent the pharyngealization of emphatic consonants (e.g., $\left.\left[\mathrm{s}^{\mathrm{c}}\right]\right)$.

\subsubsection{Standard Sundanese}

Smaller than that of Arabic, the phonemic consonantal inventory of Standard Sundanese ${ }^{2}$ has 19 consonants, classified based on two voicing qualities, five places of articulation, and seven manners of articulation, as shown in Table 2 (partly based on Von Syoc [6], Gathercole [14], and Kurniawan [15]).
1 "Modern Standard Arabic" and "Arabic" are used interchangeably throughout this paper.
2 "Standard Sundanese" and "Sundanese" are used interchangeably in this paper. 
Table 1. The phonemic consonantal inventory of Modern Standard Arabic

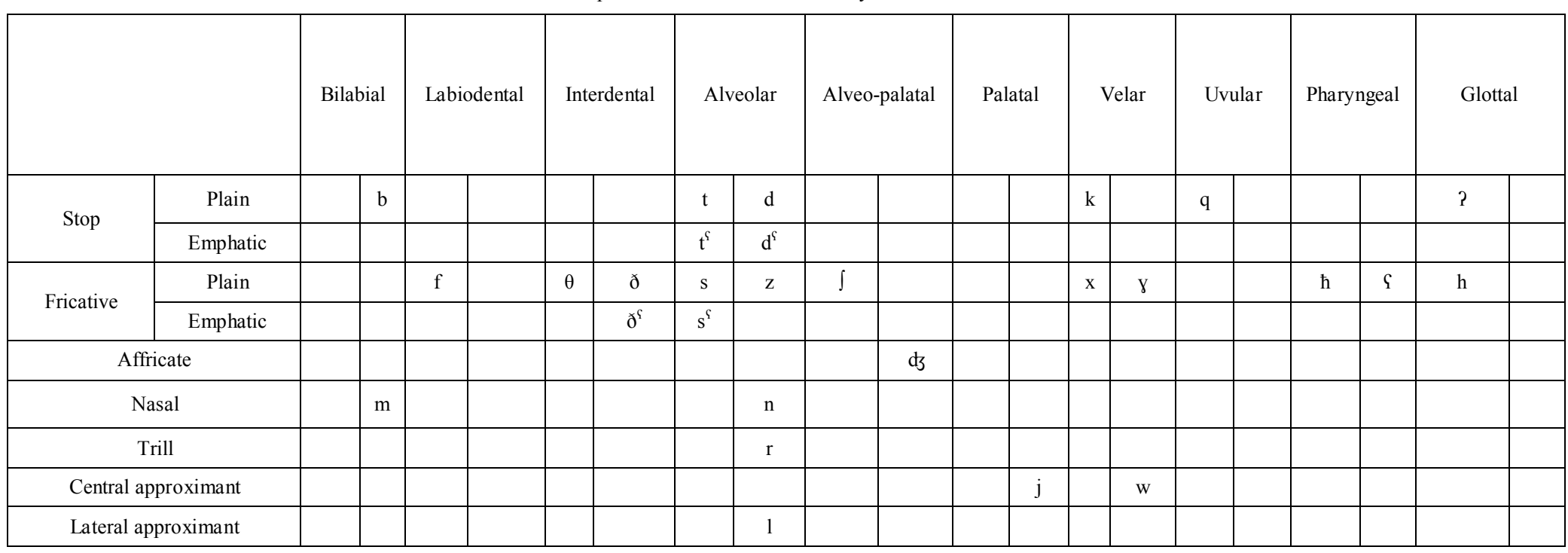

Table 2. The phonemic consonantal inventory of Standard Sundanese

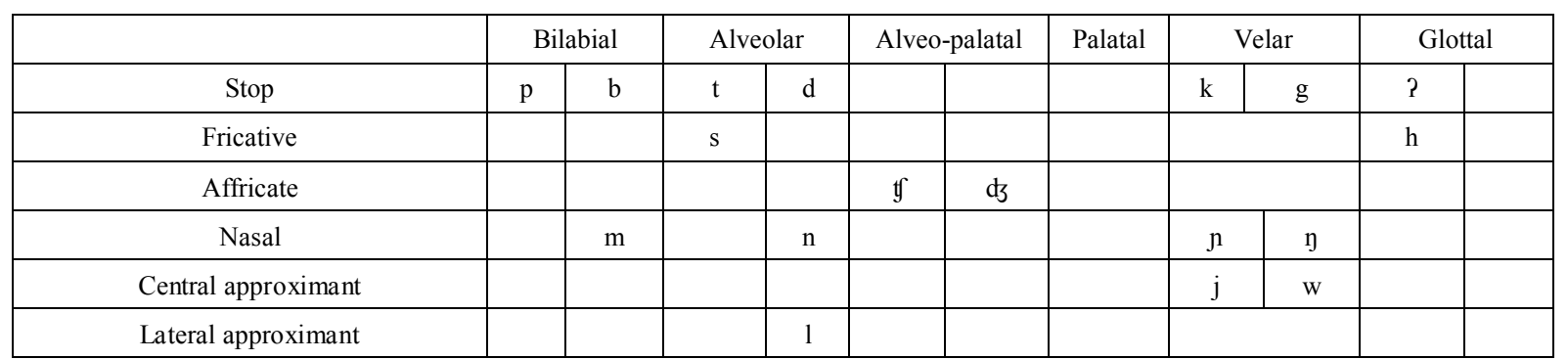




\section{Theoretical Background}

Over the last two decades, several theoretical approaches have been proposed to account for loanword adaptation. The first view is that the loanword adaptation process is purely phonological and relies on the Theory of Constraints and Repair Strategies (Paradis \& LaCharité [16]). The second and opposite view is that loanword adaptation is purely phonetic in that it is guided by the phonetic details of the incoming foreign input (Peperkamp [17]). The third view is Silverman's multiple-scansion model, according to which the adaptation process takes place at two separate levels: the Perceptual Level (at which the acoustic signal is scanned) and the Operative Level (at which the material passing the first level is subject to the phonological operations of the borrowing language) [18]. Finally, the fourth stance is that perception is inseparable from phonology. Among the supporters of this view is Best [1] who, in her Perceptual Assimilation Model (PAM), claims that the assimilation of foreign speech sounds to native phonological categories is guided by the perceived articulatory similarity between these segments. That is, the listener can detect the gestural details of the non-native speech signals and accordingly map non-native sounds to their most similar counterparts in the native sound system.

In this paper, I present data from Sundanese loanword adaptation to test the above-stated claim of PAM. To this end, I undertake my analyses within the Optimality-Theoretic framework (Prince \& Smolensky [19]). OT is a constraint-based theory in which the candidate is selected if it best satisfies a set of ranked constraints, and this candidate is known as the optimal output. Constraints are of two basic types: markedness and faithfulness. These two types of constraints may be violated. They can conflict with each other to determine the candidate. Markedness constraints guarantee/require that the optimal output is structurally well-formed (or unmarked). For example, the markedness constraint * LaBial forbids the occurrence of labial consonants in the output. Faithfulness constraints, on the other hand, demand that identity in some features be maintained between the input and output representations. To ensure such featural faithfulness, McCarthy and Prince [20] propose a family of IDENT (F) constraints which guarantee that the feature $F$ value in the input segment is identical to that in the output segment. For example, the faithfulness constraint IDENT (LABIAL) demands that the labial feature of the input segment is present in its corresponding output segment.

\section{Data}

The Arabic loanwords used in this study are primarily drawn from three sources. The first is Rigg's [21] $A$ Dictionary of the Sunda Language of Java. Considered the first published foreign language dictionary for the Sundanese language, it is comprised of hundreds of entries for foreign words with their designated source languages. The second source is Sumantri et al.'s [22] Sundanese-Indonesian Dictionary. It is based on the modern standard form of Sundanese as spoken in Bandung, the capital city of West Java and the heart of Sundanese culture. The third is Van Syoc's dissertation [6] in which lists of Sundanese words are collected from multiple sources and dictionaries. The Arabic loans selected were transcribed in IPA. Table 3 lists the consonantal correspondences to be examined.

Table 3. The consonantal adaptations attested in the Sundanese adaptation of Arabic loanwords

\begin{tabular}{|c|c|c|}
\hline Arabic & $\rightarrow$ & Sundanese \\
\hline$/ \mathrm{f} /$ & $\rightarrow$ & $/ \mathrm{p} /$ \\
\hline$/ \theta /$ & $\rightarrow$ & $/ \mathrm{s} /$ \\
\hline$/ \mathrm{J} /$ & $\rightarrow$ & $/ \mathrm{s} /$ \\
\hline$/ \mathrm{z} /$ & $\rightarrow$ & $/ \mathrm{d} /$ \\
\hline$/ \mathrm{d}^{\mathrm{s}} /$ & $\rightarrow$ & $/ \mathrm{d} /$ \\
\hline$/ \mathrm{t}^{\mathrm{s}} /$ & $\rightarrow$ & $/ \mathrm{t} /$ \\
\hline$/ \mathrm{s}^{\mathrm{s}} /$ & $\rightarrow$ & $/ \mathrm{s} /$ \\
\hline
\end{tabular}

\section{Analysis and Discussion}

In this section, I present an OT account of the adaptation of seven Arabic consonants in Standard Sundanese. The OT constraints used in accounting for the consonantal mappings in Table 3 are as follows:

\begin{tabular}{|c|c|}
\hline *Labiodental & $\begin{array}{l}\text { A consonant with a labiodental place of } \\
\text { articulation is not allowed. }\end{array}$ \\
\hline *Dental & $\begin{array}{l}\text { A consonant with a dental place of articulation } \\
\text { is not allowed. }\end{array}$ \\
\hline *Emphatic & Emphatic consonants are not allowed. \\
\hline$* / \mathrm{z} /$ & $\begin{array}{l}\text { A voiced alveolar fricative consonant is not } \\
\text { allowed. }\end{array}$ \\
\hline$* / \int /$ & $\begin{array}{l}\text { A voiceless post-alveolar fricative consonant is } \\
\text { not allowed. }\end{array}$ \\
\hline $\begin{array}{c}\text { Ident } \\
\text { (Articulator) }\end{array}$ & $\begin{array}{c}\text { An input segment and its output correspondent } \\
\text { must be identical in the major articulator. }\end{array}$ \\
\hline Ident (Voice) & $\begin{array}{l}\text { An input segment and its output correspondent } \\
\text { must be identical in voice. }\end{array}$ \\
\hline $\begin{array}{l}\text { Ident } \\
\text { (Manner) }\end{array}$ & $\begin{array}{l}\text { An input segment and its output correspondent } \\
\text { must be identical in manner of articulation. }\end{array}$ \\
\hline $\begin{array}{c}\text { Ident } \\
\text { (Stridency) }\end{array}$ & $\begin{array}{l}\text { An input segment and its output correspondent } \\
\text { must be identical in stridency }\end{array}$ \\
\hline $\begin{array}{l}\text { Ident } \\
\text { (Place) }\end{array}$ & $\begin{array}{c}\text { An input segment and its output correspondent } \\
\text { must be identical in primary place of } \\
\text { articulation. }\end{array}$ \\
\hline Ident $(\mathrm{C}) 3$ & $\begin{array}{l}\text { The input and output consonants must be } \\
\text { identical (i.e., no change of features) }\end{array}$ \\
\hline
\end{tabular}

First, considering the adaptation of Arabic /f/, as shown in Table 4, Arabic voiceless labiodental fricative /f/ is adapted as a voiceless bilabial stop in Standard Sundanese:

3DEP-IO (FEAT) (i.e., no insertion of features) and MAX-IO (FEAT) (i.e., no deletion of features) are collapsed into this constraint. 
Table 4. The adaptation of Arabic/f/ in Standard Sundanese

\begin{tabular}{|c|c|c|}
\hline Arabic & Sundanese & Gloss \\
\hline$/$ fikr/ & /pikir/ & 'think' \\
\hline /nafaqah/ & /napakah/ & 'financial support' \\
\hline$/$ nafs/ & /napsu/ & 'desire' \\
\hline$/$ munafiq/ & /munapek/ & 'hypocrite' \\
\hline$/$ fahm/ & /paham/ & 'understand' \\
\hline
\end{tabular}

To address the adaptation of Arabic/f/ into Sundanese $/ \mathrm{p} /$ in OT, one markedness constraint and five faithfulness constraints are required, as illustrated in Table 5. Given that Standard Sundanese does not allow the existence (i.e., importation) of Arabic labiodental consonants in its native phonemic system, the markedness constraint, *LABIODENTAL, is ranked high. Consequently, candidate (a) is automatically ruled out. The next two constraints are faithfulness constraints, namely IDENT (ARTICULATOR) and IDENT (VOICE). They are ranked equally highly with
*Labiodental, as Sundanese requires that the consonantal counterpart for Arabic /f/ be identical in the major articulator and the voicing quality. Any change in either of these two features is never tolerated in the Sundanese adaptation of Arabic consonants. As a result, candidate (b) is the winning candidate for satisfying both faithfulness constraints, whereas candidates (c), (d), and (e) are ruled out for violating them. Candidates (c) and (d), although fulfilling IDENT (ARTICULATOR) (both are labial), are ruled out for incurring a violation of IDENT (VOICE). Candidate (e) is excluded because it violates IDENT (ARTICUlator) (/t/ is coronal), though meeting IDENT (VOICE). Because their violations are not fatal, IDENT (Manner), Ident (Place), and Ident (C) are ranked below high-ranking *LABIODENTAL, IDENT (ARTICUlator), and IDENT (Voice), as follows: *Labiodental, IDENT (ARticulator), and IDENT (VOICE) $>>$ IDENT (MANNER) >> IDENT (PLACE) $>>$ IDENT (C).

Table 5. The OT analysis of the adaptation of Arabic /f/ into /p/ in Standard Sundanese

\begin{tabular}{|c|c|c|c|c|c|c|}
\hline Input: $/ \mathrm{f} /$ & $*$ LABIODENTAL & IDENT (ARTICULATOR) & IDENT (VOICE) & IDENT (MANNER) & IDENT (PLACE) & IDENT C) \\
\hline a. $/ \mathrm{f} /$ & $* !$ & & & & & $*$ \\
\hline b. $\sigma / \mathrm{p} /$ & & & & $*$ & $*$ & $*$ \\
\hline c. $/ \mathrm{b} /$ & & & $* !$ & $*$ & $*$ & $*$ \\
\hline d. $/ \mathrm{m} /$ & & $* !$ & $*$ & $*$ & $*$ & $*$ \\
\hline e. $/ \mathrm{t} /$ & & & & $*$ & $*$ & $*$ \\
\hline
\end{tabular}

The second adaptation is that of Arabic dental $/ \theta /$. As shown in Table 6 , Arabic $/ \theta /$ is always replaced with $/ \mathrm{s} /$ in Standard Sundanese.

Table 6. The adaptation of Arabic $/ \theta /$ in Standard Sundanese

\begin{tabular}{|c|c|c|}
\hline Arabic & Sundanese & Gloss \\
\hline 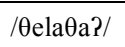 & /salasa/ & 'Tuesday' \\
\hline /AəneIn/ & $/$ senin/ & 'Monday' \\
\hline$/ \mathrm{mI} \theta \mathrm{l} /$ & $/ \mathrm{misil} /$ & 'example' \\
\hline
\end{tabular}

To explain the consonantal mapping of Arabic $/ \theta /$ onto Sundanese $/ \mathrm{s} /$, the markedness constraint (*DENTAL), in addition to the five faithfulness constraints used for the adaptation of /f/ (i.e., IDENT (ARTICULATOR), IDENT (VOICE), IDENT (MANNeR), IDENT (Place), AND IDENT (C)), is needed. The markedness constraint is high-ranked, and so are the faithfulness constraints, namely IDENT (ARTICULATOR), IDENT (VOICE), and IDENT (MANNER). The violation of any of these high-ranked constraints is considered fatal. As shown in Table 7, candidate (a) is ruled out because it violates *DENTAL: dental consonants are difficult to articulate in Sundanese. In addition, although candidates (c) and (e) conforming to *DENTAL, IDENT (ARTICUlator), and IDENT (VOICE), they lose for violating IDENT (MANNER): the manners of articulation of $/ t /$ and $/ \mathrm{t} /$, respectively, are different from that of $/ \theta /$. Moreover, candidate (d) is eliminated as a result of its disagreement with IDENT (VOICE) and IDENT (MANNER). Candidate (b) is the optimal output on the basis that it meets all four high-ranked markedness and faithfulness constraints. Since these are violated in the winning candidate, the faithfulness constraints IDENT (PLACE) and IDENT (C) are low-ranked in Table 7. Therefore, the required ranking of constraints to yield $/ \theta / \rightarrow / \mathrm{s} /$ is as follows: *DENTAL, IDENT (ARTICULATOR), IDENT (VOICE) $>>$ IDENT (MANNER) $>>$ IDENT (Place) $>>$ IDENT (C). 
Table 7. The OT analysis of the adaptation of Arabic $/ \theta /$ into /s/ in Standard Sundanese

\begin{tabular}{|c|c|c|c|c|c|c|}
\hline $\begin{array}{c}\text { Input: } \\
/ \theta /\end{array}$ & *DENTAL & $\begin{array}{c}\text { IDENT } \\
\text { (ARTICULATOR) }\end{array}$ & IDENT (VOICE) & $\begin{array}{c}\text { IDENT } \\
\text { (MANNER) }\end{array}$ & $\begin{array}{c}\text { IDENT } \\
\text { (PLACE) }\end{array}$ & IDENT (C) \\
\hline a. $/ \theta /$ & $* !$ & & & & & \\
\hline b. $ه / s /$ & & & & & $*$ & $*$ \\
\hline c. $/ \mathrm{t} /$ & & & & $* !$ & * & $*$ \\
\hline d. $/ \mathrm{d} /$ & & & $* !$ & $*$ & $*$ & $*$ \\
\hline e. $/ \mathfrak{y} /$ & & & & $* !$ & $*$ & $*$ \\
\hline
\end{tabular}

The third adaptation is that of Arabic voiceless post-alveolar fricative / $/$ into voiceless alveolar fricative /s/ in Standard Sundanese, as illustrated in Table 8.

Table 8. The adaptation of Arabic / $/$ / in Standard Sundanese

\begin{tabular}{|c|c|c|}
\hline Arabic & Sundanese & Gloss \\
\hline$/$ arifat/ & /sari?at/ & 'Islamic law' \\
\hline$/ \mathrm{Gifa} /$ & /isa/ & 'nighttime prayer' \\
\hline$/ \mathrm{SertSan} /$ & /setan/ & 'devil' \\
\hline$/ \mathrm{fukr} /$ & /sukur/ & 'praise, gratitude' \\
\hline
\end{tabular}

For Arabic $/ \mathrm{J} /$ to be adapted into $/ \mathrm{s} /$ in Sundanese, the markedness constraint $* / \mathrm{J} /$, as well as the faithfulness constraints in Table 7, is employed in Table $9 . * / \mathrm{J} /$ is ranked high with IDENT (ART ICULATOR) and IDENT (VOICE), followed by IDENT (MANNER). Any non-observance of any of the aforementioned constraints will result in the elimination of the candidate. Accordingly, candidate (a) loses because it violates */ $/$, whereas candidates (b) and (c) are eliminated as a result of their violation of IDENT (MANNER). Moreover, candidate (e), being a bilabial consonant (i.e., /p/), loses due to its nonconformity with IDENT (ARTICULATOR) as well as IDENT (MANNER). Candidate (d) is the Sundanese winning output to replace Arabic $/ \mathrm{J} /$ because it respects the high-ranked four constraints in Table 9. Finally, the IDENT (PLACE) and IDENT (C) constraints are violated in order to satisfy the higher-ranked constraints; hence, they are ranked low in the hierarchy. The Sundanese preference for adapting Arabic $/ \mathrm{J} /$ into /s/ is reflected in the following constraint ranking: */J/, IDENT

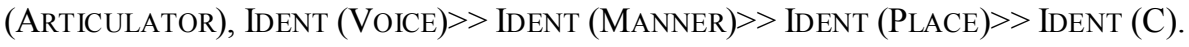

Table 9. The OT analysis of the adaptation of Arabic / / into /s/ in Standard Sundanese

\begin{tabular}{|c|c|c|c|c|c|c|}
\hline Input: $/ \mathrm{g} /$ & $* / \mathrm{g} /$ & $\begin{array}{c}\text { Ident } \\
\text { (Articulator) }\end{array}$ & $\begin{array}{c}\text { Ident } \\
\text { (Voice) }\end{array}$ & Ident (Manner) & Ident (Place) & Ident (C) \\
\hline a. $/ \mathrm{g} /$ & $* !$ & & & & & $* !$ \\
\hline b. $/ \mathrm{g} /$ & & & & $* !$ & $*$ & $*$ \\
\hline c. $/ \mathrm{t} /$ & & & & & $*$ & $*$ \\
\hline d. $\sigma / \mathrm{s} /$ & & $* !$ & & $*$ & $*$ & $*$ \\
\hline e. $/ \mathrm{p} /$ & & & & & $*$ \\
\hline
\end{tabular}

When it comes to Arabic/z/, it is substituted with /dz/ in Sundanese, as exemplified in Table 10:

Table 10. The adaptation of Arabic /z/ in Standard Sundanese

\begin{tabular}{|c|c|c|}
\hline Arabic & Sundanese & Gloss \\
\hline /zakat/ & /dgakat/ 'alms' \\
\hline /zaman/ & /dgaman/ & 'time' \\
\hline /rizk/ & /radzeki/ & 'livelihood' \\
\hline /zertun/ & /dgetun/ & 'olive' \\
\hline
\end{tabular}

As shown in Table 11, the constraints */z/, IDENT (ARTICULATOR), IDENT (VOICE), and IDENT (STRIDENCY) are ranked high and outrank IDENT (MANNER). IDENT (PLACE) and IDENT (C) are low-ranked because their violations are minimal. However, the violation of any of the four high-ranked constraints will rule out any candidate. Consequently, candidate (c) is the winning candidate because it fulfills high-ranked */z/, IDENT (ARTICULATOR), IDENT (VOICE), and IDENT (STRIDENCY). The only difference between the winning candidate and candidate (d) is that the latter violates IDENT (STRIDENCY) and, therefore, it is excluded. If it were not for IDENT (STRIDENCY), there should be a tie between these two candidates. For that reason, IDENT (MANNER) is ranked below IDENT (STRIDENCY). 
Table 11. The OT analysis of the adaptation of Arabic /z/ into /dz/ in Standard Sundanese

\begin{tabular}{|c|c|c|c|c|c|c|c|}
\hline Input: / z/ & $* / z /$ & $\begin{array}{c}\text { IDENT } \\
\text { (ARTICULATOR) }\end{array}$ & $\begin{array}{c}\text { IDENT } \\
\text { (VOICE) }\end{array}$ & $\begin{array}{c}\text { IDENT } \\
\text { (STRIDENCY) }\end{array}$ & $\begin{array}{c}\text { IDENT } \\
\text { (MANNER) }\end{array}$ & $\begin{array}{c}\text { IDENT } \\
\text { (PLACE) }\end{array}$ & IDENT (C) \\
\hline a. $|z|$ & $* !$ & & & & & & $*$ \\
\hline b. $/ \mathrm{s} /$ & & & $* !$ & & & & $*$ \\
\hline c. $\sigma / d z /$ & & & & & $*$ & $*$ & $*$ \\
\hline d. $/ \mathrm{d} /$ & & & & $* !$ & $*$ & & $*$ \\
\hline e. $/ \mathrm{t} /$ & & & $* !$ & $*$ & $*$ & & $*$ \\
\hline f. $/ \mathrm{b} /$ & & $* !$ & & $*$ & $*$ & * & $*$ \\
\hline
\end{tabular}

Moreover, candidate (a) loses as Sundanese prohibits the importation of / $\mathrm{z} /$ into its phonemic inventory. Candidate (b) is eliminated because of its violation of IDENT (VOICE). Furthermore, candidates (e) and (f) are eliminated because they violate high-ranked IDENT (VOICE) and IDENT (ARTICULATOR) respectively, in addition to their nonconformity with IDENT (STRIDENCY). To ensure the adaptation of Arabic/z/ into Sundanese/dz/, the constraints are ranked in the following order: */z/, IDENT (ARTICULATOR), IDENT (VOICE), IDENT (STRIDENCY)>> IDENT (MANNER) >>IDENT (PLACE) >> IDENT (C).

Regarding Arabic alveolar emphatic $/ \mathrm{d}^{\mathrm{f}} /, \mathrm{t}^{\mathrm{f}} /$, and $/ \mathrm{s}^{\mathrm{f}} /$, they are mapped onto their Sundanese non-emphatic counterparts, namely/d/, /t/, and /s/ respectively, as shown by the Arabic loanwords in Table 12.

Table 12. The adaptation of Arabic $/ \mathrm{d}^{\mathrm{\varsigma}} /, / \mathrm{t}^{\mathrm{\varsigma}} /$, and $/ \mathrm{s}^{\mathrm{s}} /$ in Standard Sundanese

\begin{tabular}{|c|c|c|}
\hline Arabic & Sundanese & Gloss \\
\hline$/ t^{\mathrm{s}}$ alaq/ & /talak/ & 'divorce' \\
\hline$/ t^{\mathrm{f}} \mathrm{ahir} /$ & /tahir/ & 'clean' \\
\hline$/$ qert $^{\mathrm{f}} \mathrm{as}^{\mathrm{q}} /$ & /kertas/ & 'paper' \\
\hline /bat ${ }^{\mathrm{f} i l} /$ & /batil/ & 'invalid' \\
\hline$/ \mathrm{rid}^{\mathrm{G}} \mathrm{a} /$ & /rido/ & 'sincere' \\
\hline$/$ herd ${ }^{\S} /$ & /hed/ & 'menstrual cycle' \\
\hline /wud'u?/ & /wudu/ & 'ablutions' \\
\hline$/ \mathrm{s}^{\mathrm{S}} \mathrm{abr} /$ & /sabar/ & 'patience' \\
\hline /s ifah/ & /sipat/ & 'attribute' \\
\hline /nas ${ }^{\mathrm{S}} \mathrm{ib} /$ & /nasib/ & 'fate' \\
\hline /has ${ }^{\mathrm{c}} \mathrm{il} /$ & /hasil/ & 'result' \\
\hline
\end{tabular}

Table 13. The OT analysis of the adaptation of Arabic $/ \mathrm{d}^{\mathrm{f}} /$ into $/ \mathrm{d} /$ in Standard Sundanese

\begin{tabular}{|c|c|c|c|c|c|c|}
\hline Input: $/ \mathrm{d}^{\mathrm{\varsigma}} /$ & *EMPHATIC & IDENT (ARTICULATOR) & IDENT (VOICE) & IDENT (MANNER) & IDENT (PLACE) & IDENT (C) \\
\hline a. $/ \mathrm{d}^{\mathrm{S}} /$ & $* !$ & & & & & \\
\hline b. /b/ & & $* !$ & & & $*$ & $*$ \\
\hline c. $/ \mathrm{d} / \mathrm{d}$ & & & & $* !$ & * & $*$ \\
\hline d. $/ \mathrm{t} /$ & & & $* !$ & & & $*$ \\
\hline e. $/ \mathrm{s} /$ & & & $* !$ & $*$ & & $*$ \\
\hline f. $/ \mathrm{j} /$ & & & & $* !$ & $*$ & $*$ \\
\hline g. $\sigma / d /$ & & & & & & $*$ \\
\hline
\end{tabular}

Table 14. The OT analysis of the adaptation of Arabic $/ \mathrm{t}^{\mathrm{s}} /$ into $/ \mathrm{t} /$ in Standard Sundanese

\begin{tabular}{|c|c|c|c|c|c|c|}
\hline Input: $/ \mathrm{t}^{\mathrm{s}} /$ & *EMPHATIC & IDENT (ARTICULATOR) & IDENT (VOICE) & IDENT (MANNER) & IDENT (PLACE) & IDENT (C) \\
\hline a. $/ \mathrm{t}^{\mathrm{s}} /$ & $* !$ & & & & & \\
\hline b. $/ \mathrm{p} /$ & & $* !$ & & & $*$ & $*$ \\
\hline c. $/ \mathfrak{g} /$ & & & & $* !$ & $*$ & * \\
\hline d. $/ \mathrm{d} /$ & & & $* !$ & & & $*$ \\
\hline e. /s/ & & & & $* !$ & & $*$ \\
\hline f. $\rightarrow / t /$ & & & & & & $*$ \\
\hline
\end{tabular}


Table 15. The OT analysis of the adaptation of Arabic $/ \mathrm{s} /$ into $/ \mathrm{s} /$ in Standard Sundanese

\begin{tabular}{|c|c|c|c|c|c|c|}
\hline Input: $/ \mathrm{s}^{\mathrm{s}} /$ & *EMPHATIC & IDENT (ARTICULATOR) & IDENT (VOICE) & IDENT (MANNER) & IDENT (Place) & IDENT (C) \\
\hline a. $/ \mathrm{s}^{\mathrm{s}} /$ & $* !$ & & & & & \\
\hline b. $/ \mathrm{k} /$ & & $* !$ & & $*$ & $*$ & * \\
\hline c. $/ \mathrm{t} /$ & & & & $* !$ & & * \\
\hline d. $/ \mathrm{d} /$ & & & $* !$ & $*$ & & $*$ \\
\hline e. $/ \mathrm{h} /$ & & $* !$ & & & $*$ & * \\
\hline f. $/ \mathrm{t} /$ & & & & $* !$ & $*$ & $*$ \\
\hline g. $\rightarrow / \mathrm{s} /$ & & & & & & $*$ \\
\hline
\end{tabular}

As listed in Tables 13, 14, and 15, one markedness constraint (i.e., *EMPHATIC) and five faithfulness constraints (i.e., IDENT (ARTICULATOR), IDENT (VOICE), IDENT (ManNer), IDENT (Place), and IDENT (C)) are required to elucidate the adaptations of Arabic emphatics in Standard Sundanese.

As an effect of the high-ranked *EMPHATIC constraint, candidate (a) in Tables 13, 14, and 15 is excluded. This is because Sundanese phonology does not allow the importation of Arabic consonants in general, and the emphatic consonants in particular. Next, candidate (b) in Tables 13, 14, and 15 loses for violating high-ranked IDENT (ARTICULATOR). Candidate (b) is a labial consonant in Tables 13 and 14, whereas it is a dorsal consonant (i.e., $/ \mathrm{k} /$ ) in Table 15. Moreover, for the same violation, candidate (e) in Table 15 is eliminated; /h/ uses the glottal articulator. Sundanese prefers to maintain the same major articulator when adapting Arabic consonants into native counterparts.

Candidate (c) in Tables 13, 14, and 15 is ruled out due to the fact that the Sundanese outputs (i.e., $/ \mathrm{d} / /, / \mathrm{t} /$, and $/ \mathrm{t} /$ ) differ from the corresponding Arabic inputs (i.e., $/ \mathrm{d}^{\mathrm{s}} /, / \mathrm{t}^{\mathrm{s}} /$, and $/ s^{\mathrm{s}} /$ respectively) in the manner of articulation. Candidate (e) in Table 14 and candidate (f) in Tables 13 and 15 are eliminated for the same reason.

Candidate (d) in Tables 13, 14, and 15 is ruled out as a candidate for replacing Arabic inputs $/ \mathrm{d}^{\mathrm{S}} /, 1 \mathrm{t}^{\mathrm{S}} /$, and $/ \mathrm{s}^{\mathrm{s}} /$ respectively. This is because Sundanese candidates output $/ \mathrm{t} /$, /d/, and /d/ do not satisfy IDENT (VOICE). Furthermore, candidate (e) in Table 13 loses because it is different from the source input in voice (as well as manner). Sundanese always militates against the adaptation of Arabic alveolar consonants into native counterparts with different voicing. Candidate (g) is the optimal output in Tables 13, 14, and 15 as it conforms to the three high-ranking faithfulness constraints, in addition to the markedness constraint *EMPHATIC.

Finally, given that a change in the source place feature or any source features in general is rendered least serious in the Sundanese adaptation of Arabic emphatics, the two faithfulness constraints IDENT (PLACE) and IDENT (C) are ranked low enough so that they have no observable effects. On the other hand, differences in major articulator, voice, or manner between the source coronal alveolar emphatic input and its Sundanese native output incur the most serious violations; thereby, there is total dominance of higher-ranked constraints IDENT (ARTICULATOR), IDENT (VOICE), and IDENT (MANNER), as well as the markedness constraint, *EMPHATIC, over lower-ranked constraints IDENT (Place) and IDENT (C), as summarized in the following ranking: *EMPHATIC, IDENT (ARTICULATOR), Ident (Voice) $>>$ Ident (ManNer) $>>$ IDENT (Place) $>>$ IDENT (C).

\section{Conclusions}

The study examined the Sundanese adaptation of seven Arabic consonants, namely $/ \mathrm{f} /, / \theta /, / \mathrm{z} /, / \mathrm{d}^{\mathrm{s}} /, / \mathrm{t}^{\mathrm{s}} /, / \mathrm{s}^{\mathrm{s}} /$, and $/ \mathrm{J} /$, and confirmed the major role of featural faithfulness in their adaptations. In doing so, the paper contributes to the field of loanword phonology in general, and to the scarce literature on Sundanese loanword phonology. In adapting Arabic consonants to native counterparts, Standard Sundanese most importantly preserves the source consonant's major articulator and voice (for all seven consonants), followed next by manner of articulation (for all consonants except $/ \mathrm{f} /$ and $/ \mathrm{z} /$ ) and, lastly, by stridency (for $/ \int /, \mid \mathrm{z} /$, and $/ \mathrm{s}^{\mathrm{s}} /$ ) features. In contrast, closeness between the source input and the native input in terms of place of articulation feature (i.e., IDENT (PLACE)) was not firmly adhered to in the data analyzed. In OT terms, the faithfulness constraints IDENT (ARTICULATOR) and IDENT (VOICE) (and sometimes IDENT (MANNER) and IDENT (STRIDENCY)) were decisive in determining the winning output; therefore, they outrank low-ranking constraints, namely IDENT (PLACE) and IDENT (C), whose violations were always least serious in order to satisfy the high-ranked constraints. Moreover, ranked equally with high-ranking faithfulness constraints are the markedness constraints that militate against the importation of any of the seven Arabic consonants in the Sundanese consonantal inventory. Given that most of the articulatory information of the Arabic consonant is maintained in the Sundanese correspondent, the Sundanese adaptation of Arabic loanwords examined in the data corroborates the Perceptual Assimilation Model (Best [1]), because the 
Sundanese listener perceptually adapts the Arabic consonant to the most articulatorily similar native consonant in Standard Sundanese.

\section{Acknowledgements}

The author would like to thank both the Deanship of Scientific Research and the College of Arts Research Center at King Saud University for funding this research project.

\section{REFERENCES}

[1] C. Best. A direct realist view of cross-language speech perception, In W. Strange (ed.). Speech perception and linguistic experience: Theoretical and methodological issues in cross-language speech research, 171-204, Baltimore: York Press, 1995.

[2] The Online Encyclopedia of Writing Systems and Languages. Sundanese (Basa Sunda), Online available from https://www.omniglot.com/writing/sundanese.php.

[3] B. Nothofer. Dialektgeographische Untersuchung des Sundanesischen und des Entlang der Sundanesischen Sprachgrinze Gesprochenen Javanischen und Jakarta-Malaiischen, Philosophischen Fakultat der Universitảt zu Köln, Ersten Teil, 1977.

[4] Z. Arifin. Bahasa Sunda dialek Priangan, Jurnal Pujangga, Vol. 2, No. 1, 1-44, 2016.

[5] E. Anderson, Speech levels: The case of Sundanese, Pragmatics, Vol. 3, No. 2, 107-136. 1993.

[6] W. Van Syoc. The phonology and morphology of the Sundanese language, Ph.D. thesis, University of Michigan, 1959.

[7] L. Manger. The Hadrami Diaspora: Community-building on the Indian Ocean Rim, Berghahn Books, New York, 2010.

[8] F. Jacobsen. Marriage patterns and social stratification in present Hadrami Arab societies in Central and Eastern Indonesia, Asian Journal of Social Science, Vol. 35, 472-87, 2007.

[9] F. Jacobsen. Hadrami Arabs in Present-day Indonesia: An Indonesia-oriented Group with an Arab Signature, Routledge New York, 2009.

[10] M. C. Bateson. Arabic Language Handbook, Georgetown University Press, Washington, DC, 1967.

[11] K. Ryding. A Reference Grammar of Modern Standard Arabic, Cambridge University Press, Cambridge, UK, 2005.

[12] S. Al-Ani. Arabic Phonology: An Acoustical and Physiological Investigation, Mouton, The Hague, 1970.

[13] J. Watson. The Phonology and Morphology of Arabic. Oxford University Press, New York, 2007.
[14] G. Gathercole. A closer look at Sundanese phonology, Kansas Working Papers in Linguistics, Vol. 2, 134-143, 1977.

[15] E. Kurniawan. Sundanese nasal substitution: An Optimality Theoretic analysis, NUSA, Vol.6, 49-68, 2016.

[16] C. Paradis, D. LaCharité. Preservation and minimality in loanword adaptation, Journal of Linguistics, Vol. 33, 379-430, 1997.

[17] S. Peperkamp. A psycholinguistic theory of loanword adaptations, BLS, Vol. 30, 341-352, 2005.

[18] D. Silverman. Multiple scansions in loanword phonology: Evidence from Cantonese, Phonology, Vol. 9, 289-328, 1992.

[19] A. Prince, P. Smolensky. Optimality Theory: Constraint interaction in generative grammar. MS, Rutgers University and University of Colorado, Bolder, 1993.

[20] J. J. McCarthy, A. Prince. Faithfulness and reduplicative identity, In J. Beckman, L. Dickey, and S. Urbanczyk (eds). University of Massachusetts Occasional Papers in Linguistics 18: Papers in Optimality Theory, 249-384, Amherst, GLSA Publications, 1995.

[21] J. Rigg. A Dictionary of the Sunda Language, Lange \& Co., Jakarta, 1862.

[22] M. Sumantri, A. Djamaludin, A. Patoni, M. Koerdi, M.O. Koesman, E.S. Adisastra. Kamus Sunda-Indonesia, Pusat Pembinaan dan Pengembangan Bahasa, Jakarta, 1985. 